\title{
PEMANFAATAN KICK FOOT SENSOR UNTUK MEKANISME BUKA TUTUP BAGASI KENDARAAN
}

\author{
Ian Hardianto Siahaan ${ }^{1}$, Andreas Sastro Wibowo ${ }^{2}$ \\ 1,2 Sustainable Mechanical Engineering \& Design Program, Universitas Kristen Petra \\ 1ian@petra.ac.id \\ 2andreas.wibowo99@gmail.com
}

\begin{abstract}
Abstrak - Seiring perkembangannya, produsen mobil semakin meningkatkan fitur keselamatan dan keamanan pada setiap produknya. Pada saat ini, unsur keselamatan dan keamanan ini menjadi sasaran penting dalam pengembangan keberadaan beragam fitur yang tersedia di dalam sebuah kendaraan. Dalam penelitian ini diterapkan sebuah fitur power back door dengan pemanfaatan kick foot sensor sebagai input data untuk membuka dan menutup bagasi kendaraan melalui aktuatornya. Fitur ini menggunakan sensor kaki sehingga tidak perlu menekan tombol apapun, hanya mengarahkan kaki ke bawah bemper belakang dan secara otomotis sensor akan membaca dan membuka pintu bagasi tersebut. Fitur ini sangat membantu penumpang yang hendak memuat barang bawaan ke bagasi namun kedua tangannya sedang membawa barang seperti tas atau kantong plastik belanjaan. Ada beberapa tahapan yang dilakukan dalam penelitian ini. Tahap pertama, spesifikasi motor aktuator yang diperlukan meliputi gaya dan torsi dilakukan secara analisa freebody diagram agar dapat melakukan gerakan untuk membuka dan menutup bagasi. Tahap kedua, pintu bagasi dilakukan pengujian pada saat kondisi membuka dan menutupnya. Dari hasil pengujian diperoleh waktu untuk membuka bagasi ratarata sebesar 11,79 detik, sedangkan waktu untuk menutupnya rata rata sebesar 11,56 detik. Waktu yang diperoleh ini lebih cepat dibanding target awal perancangan yang ditetapkan 15 detik baik saat membuka maupun menutup bagasi. Sedangkan sensitivitas motion sensornya kemampuannya berada pada range jarak antara $20 \mathrm{~mm}$ dan $400 \mathrm{~mm}$ pada saat kaki tepat berada di bawah sensor.
\end{abstract}

Kata Kunci- aktuator; bagasi; sensor.

\begin{abstract}
Along with its development, car manufacturers are increasingly improving safety and security features in each of their products. Currently, this element of safety and security has become an important target in the development of the existence of various features that exist in a vehicle. In this study, the power back door feature is implemented by using the kick foot sensor as input data to open and close the trunk of the vehicle through the actuator. This feature uses a foot sensor so you don't have to press any buttons, just point your foot under the rear bumper and the sensor will automatically read and open the trunk door. This feature is very helpful for passengers who want to put their luggage in the trunk but have both hands to carry items such as bags or plastic shopping bags. There are several stages carried out in this research. In the first stage, the specification of the required actuator motor, including force and torque, is carried out by analyzing the free body diagram to be able to open and close the trunk. In the second stage, the trunk door is tested when the condition is open and close. From the test results, the average time to open the trunk is 11.79 seconds, while the average time to close the trunk is 11.56 seconds. The time obtained is faster than the initial design target set, which is 15 seconds both when opening and closing the trunk. While the sensitivity of the motion sensor can range from $20 \mathrm{~mm}$ to $400 \mathrm{~mm}$ when the foot is directly under the sensor.
\end{abstract}

Keywords_-actuator; baggage; sensors.

\section{PENDAHULUAN}

Mekanisme pembuka pintu bagasi pada kendaraan mengalami perkembangan secara berkelanjutan dari mekanisme berbasis kunci dan tuas pembuka bagasi secara mekanikal selanjutnya berkembang menjadi secara elektrik. Penggunaan driver bertenaga listrik untuk menaikkan dan menurunkan tutup bagasi otomotif, pintu lift, dan penutup mesin menjadi lebih umum. Mekanisme untuk megangkat bagasi umumnya menggunakan tipe brushed motor DC yang merespons perintah dari sakelar kontrol di kabin atau sakelar pada key. Driver ini biasanya memiliki serangkaian roda gigi mekanis dengan keunggulan mekanis untuk memasok torsi yang cukup untuk memindahkan beban mekanis yang besar.
Keuntungan ini meningkatkan torsi efektif dari motor dan menurunkan kecepatan putaran. Lengan mekanis dan hubungan yang terhubung mengubah rotasi menjadi gaya yang digunakan untuk membuka atau menutup pintu bagasi [1].

Salah satu inovasi otomotif sebagai penunjang kenyamanan yang sudah mulai banyak diterapkan produsen pada berbagai tipe kendaraannya, baik dari kelas menengah bahkan kelas premium adalah mekanisme pembuka pintu bagasi dengan secara elektrik atau yang biasa disebut dengan power tailgate. Namun mekanisme bagasi secara elektrik yang sudah ada saat ini telah menggunakan sensor lain yang lebih praktis, seperti pemanfaatan sensor speech recognition. 
Sebagaimana diketahui bahwa speech recognition adalah sebuah kemampuan yang dimiliki oleh mesin atau aplikasi untuk mengindentifikasi kata dan frasa yang terdapat dalam bahasa lisan [2]. Kata dan frasa tersebut akan diolah dan dirubah menjadi sebuah format yang dapat dibaca oleh mesin atau aplikasi tersebut. Sistem sensor ini dapat dikatakan berhasil namun masih ada berbagai kelemahan yang dihadapinya [3]. Kelemahan yang dimaksud, yaitu bahwa speech recognition sebagai teknologi dasar VUI masih belum sempurna. Sebagaimana dilansir pada The Washington Post, Google Assistant, VUI yang tersimpan dalam Google Home, masih sulit memahami dialek dan bahasa selain bahasa Inggris. Dalam percobaan menggunakan 70 perintah suara yang dilakukan manusia pada Google Home, secara keseluruhan Google Assistant memiliki tingkat akurasi hanya berkisar 83 persen. Namun, pada akses pada bahasa tertentu nilainya turun menjadi lebih rendah. Akses bahasa Inggris yang dituturkan di Pantai Timur Amerika Serikat, misalnya, memiliki tingkat akurasi 2,5 persen lebih rendah dibandingkan akses bahasa Inggris yang digunakan di wilayah Barat Amerika Serikat. Meski belum sempurna, Richard Lippmann dalam penelitian berjudul "Speech Recognition by Machine and Humans" menyatakan bahwa teknologi speech recognition saat ini masih terus mengalami peningkatan kemampuan dengan tingkat kesalahan yang masih bisa ditoleransi. Kesalahan sistem speech recognition dalam mengenali suara meningkat antara 20 hingga 40 persen jika kondisi uji coba di luar ruangan tertutup tanpa kebisingan baik untuk ucapan spontan dan $23 \%$ dengan saluran variabilitas dan kebisingan [4]. Kinerja suara manusia yang sangat baik diperoleh ketika bagian kalimat pendek 2-4 detik diekstraksi dari ucapan spontan yang menyarankan bahwa pekerjaan lebih lanjut diperlukan pada bahasa permodelan dan algoritma yang dapat dengan cepat beradaptasi untuk variabilitas pembicara, saluran, dan gaya pembicara menggunakan hanya dengan segmen kalimat pendek [5]. Dalam hal untuk mengurangi kebisingan latar belakang yang dihasilkan oleh lingkungan luar, pengoptimalkan konfigurasi susunan mikrofon dapat meningkatkan kualitas ucapan yang diperoleh sebagai terlihat dalam studi penelitian dengan judul 'An evolutionary algorithm to optimize the microphone array configuration for speech acquisition in vehicles'. Namun, dalam sistem pengenalan suara untuk kendaraan ini, efisiensi yang dicapai hanya $78,57 \%[6]$.

Berdasarkan permasalahan yang telah dijelaskan tersebut, penelitian mengembangkan mekanisme pembuka pintu bagasi secara elektrik dengan memanfaatkan kick foot sensor untuk mengantispasi beberapa kelemahan yang mungkin terjadi saat membuka ataupun menutup bagasi dengan mekanisme sensor speech recognition. Pertimbangan berikutnya yang menjadi dasar pengembangan mekanisme bahwa power tailgate awalnya diciptakan, karena para produsen mobil melihat bahwa timbul kesusahan untuk membuka pintu bagasi mobil ketika pengguna mobil sedang dalam keadaan membawa barang yang cukup banyak maupun ketika sedang menggendong anak maka kegiatan untuk membuka pintu bagasi juga akan semakin sulit. Seiring berkembangnya
Revolusi Industri 4.0, sistem power tailgate juga ikut mengalami perkembangan cukup pesat bahkan dapat meminimalisasi error selama interaksi human learning process [7]. Pengendara bisa membuka bagasi belakang dengan ayunan kaki tanpa harus repot menekan remote atau cara manual. Pada awalnya, power tailgate mempunyai mekanisme penutupan pintu bagasi yang lama dan juga terlalu membanting pintu bagasi, sekarang sistem power tailgate sudah bisa mempunyai sistem penutupan yang lebih cepat dan lebih halus dengan kinerja aktuator yang memadai. Selain membuka dan menutup pintu bagasi secara otomatis, fitur power tailgate pun bisa diatur ketinggian bukaanya. Pengaturan ini dimanfaatkan jika kendaraan sedang berada di lokasi yang beratap rendah, atau pengguna sedang tidak menginginkan untuk membuka lebar pintu bagasi kendaraan tersebut.

\section{METODE}

Tahapan pertama yang dilakukan pada penelitian ini menetapkan model pintu bagasi kendaraan yang digunakan. Sebagaimana dijelaskan dalam gambar 1.
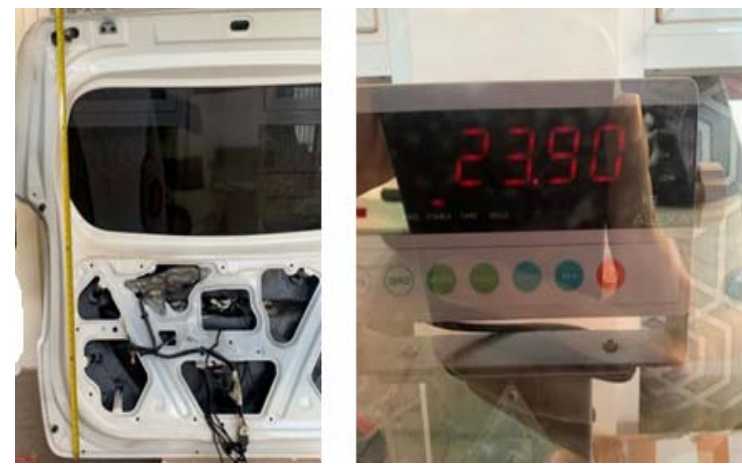

Gbr. 1 Proses penimbangan dan pengukuran pintu bagasi kendaraan

Setelah dilakukan pengukuran dan penimbangan bagasi pintu belakang tersebut dilakukan analisa gaya, sebagai ditujukkan dalam gambar 2.

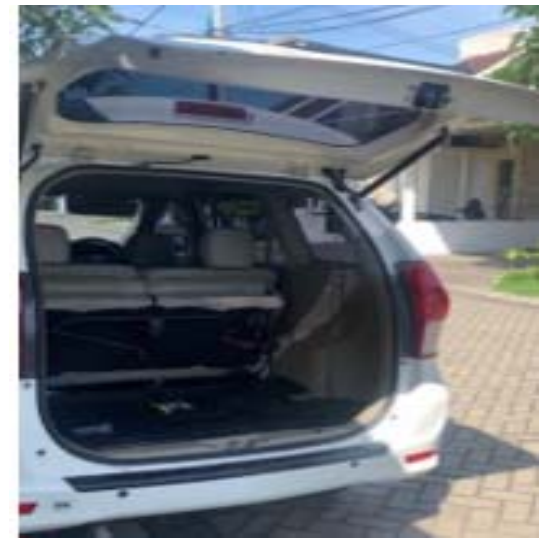

Gbr. 1 Mekanisme membuka bagasi pintu belakang kendaraan 
Selanjutnya dari tampak depan kendaraan di tampilkan free body diagram sebagai ditunjukkan dalam gambar 3 .

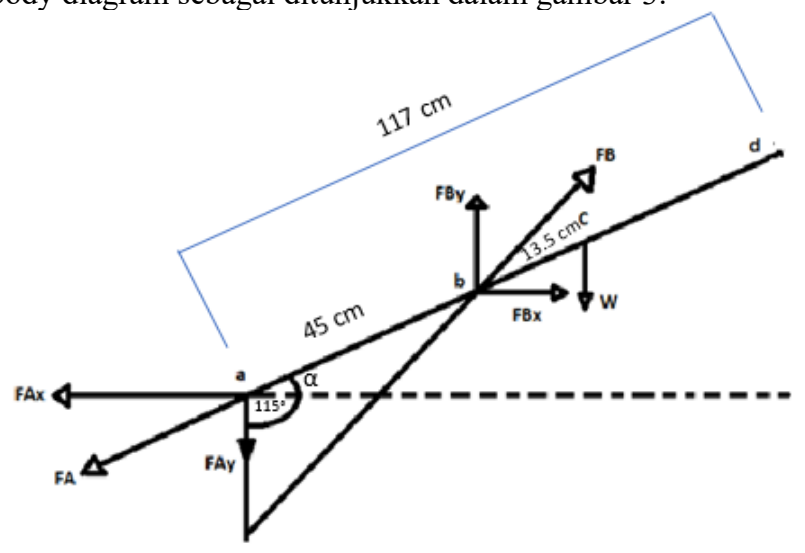

Gbr. 3 Free body diagram pintu bagasi serta dimensinya

Besarnya gaya yang diperlukan untuk dapat menggerakkan aktuator dilakukan menggunakan analisa Hukum Newton berdasarkan analisa free body diagram di atas, sebagai berikut.

PARAMETER RANCANGAN

\begin{tabular}{|c|c|c|}
\hline Simbol & \multicolumn{2}{|c|}{ Spesifikasi Bagasi } \\
\hline $\mathrm{a}$ & \multicolumn{2}{|l|}{ Titik atas bagasi } \\
\hline $\mathrm{b}$ & \multicolumn{2}{|l|}{ Engsel aktuator } \\
\hline c & \multicolumn{2}{|c|}{ Titik berat pintu bagasi } \\
\hline $\mathrm{d}$ & \multicolumn{2}{|l|}{ Titik bawah bagasi } \\
\hline $\mathrm{F}, \mathrm{FB}$ & \multicolumn{2}{|l|}{ Gaya aktuator } \\
\hline $\mathrm{m}$ & Massa bagasi & $23,9 \mathrm{~kg}$ \\
\hline $\mathrm{D}$ & Diameter aktuator & $15 \mathrm{~mm}$ \\
\hline $\mathrm{p}$ & Pitch ulir trapesium & $6 \mathrm{~mm}$ \\
\hline$\mu$ & Koefisien gesek & 0,125 \\
\hline$\alpha$ & Face of angle & $15^{\circ}$ \\
\hline
\end{tabular}

$$
\begin{aligned}
& \mathrm{W}=\mathrm{m} \times \mathrm{g} \\
& =23.9 \times 9.8 \mathrm{~m} / \mathrm{s}^{2} \\
& =234.22 \mathrm{~N} \\
& 0=+2 \Sigma_{\mathrm{ma}}=- \text { W.ac. } \sin \alpha+\text { FBy.ab.sin }(\alpha)+ \\
& \text { FBx.ab. } \cos (\alpha) \\
& 0=+\sum \Sigma_{\mathrm{mb}}=-\mathrm{W} \cdot \mathrm{bc} \cdot \sin \alpha+\text { FAy.ab. } \sin (\alpha)- \\
& \text { FAx.ab.cos }(\alpha) \\
& 0=+\Rightarrow \Sigma F x=-F A x+F B x \\
& 0=+\rrbracket \Sigma F y=W-\text { FBy }+ \text { FAy } \\
& F A x=F A \cos \beta=F A \cos (-90+\alpha) \\
& \mathrm{FAy}=\mathrm{FA} \sin (\alpha-90)
\end{aligned}
$$

Torsi motor yang dipergunakan untuk memutar ulir, dihitung dengan menggunakan persamaan berikut ini [8], [9].

Menaikkan beban:

$\mathrm{T}=\mathrm{F} \mathrm{d} / 2 \tan \left(\varphi^{\prime}+\theta\right)$

Menurunkan beban:

$$
\mathrm{T}=\mathrm{F} \mathrm{d} / 2 \tan \left(\varphi^{\prime}-\theta\right)
$$

$\tan \theta=\mathrm{L} /(\Pi \mathrm{d})$ $\tan \varphi^{\prime}=\mu / \cos \alpha$

TABEL III

HUBUNGAN PARAMETER THREAD PITCH-DIAMETER

\begin{tabular}{|c|c|}
\hline $\mathbf{D}(\mathbf{m m})$ & $\mathbf{p}(\mathbf{m m})$ \\
\hline 10,12 & 3 \\
\hline 15 & 4 \\
\hline 20 & 5 \\
\hline 25 & 6 \\
\hline 30,35 & 8 \\
\hline 40,45 & 10 \\
\hline 50,55 & 12 \\
\hline 60,65 & 13 \\
\hline 70,75 & 14 \\
\hline 80,85 & 15 \\
\hline 90,95 & 16 \\
\hline 100 & 17 \\
\hline
\end{tabular}

Gaya yang yang diperlukan aktuator optimal, diperoleh dengan menggunakan persamaan (3), yaitu pada $\alpha_{\text {maks }}=62^{\circ}$ :

$\Sigma_{\mathrm{mb}}=-234.22 \times 0.135 \times \sin \left(62^{\circ}\right)+\mathrm{FA} \sin \left(62^{\circ}-90^{\circ}\right) \times 45 \times$ $\sin \left(62^{\circ}\right)-\mathrm{FA} \cos \left(-90^{\circ}+62^{\circ}\right) \times 45 \times \cos \left(62^{\circ}\right)$

$=-234.22 \times 0.135 \times 0.972+$ FA $\times 0.382 \times 0.45 \times 0.972$

- FA $0.923 \times 0.45 \times(-0.233)$

$\mathrm{FA}=54.165 \mathrm{~N}$

Selanjutnya gaya FA tersebut diuraikan ke arah sumbu, sebagai berikut:
$\mathrm{FAx}=\mathrm{FA} \cdot \cos \left(-28^{\circ}\right)$
$\mathrm{FAx}=52.14 \mathrm{~N}$
FAy $=$ FA $\cdot \sin \left(-28^{\circ}\right)$
FAy $=98.061 \mathrm{~N}$
$\Sigma \mathrm{Fy}=\mathrm{W}-\mathrm{FBy}+\mathrm{FAy}$
$0=234.22-\mathrm{FBy}+98.061$
FBy $=332.52 \mathrm{~N}$
$\mathrm{FBx}=52.14 \mathrm{~N}$
$\mathrm{FB}=\sqrt{\mathrm{FS}^{2}+5 \mathrm{~F}^{2} y^{2}}$
$\mathrm{FB}=\sqrt{-52,14^{2}+332,5^{2}}$
$=336.583 \mathrm{~N}$

Besar sudut $(\alpha)$ yang diujikan dari rentang $0^{\circ}-115^{\circ}$ incremental $1^{\circ}$ dan diperoleh hasil tertinggi pada sudut $62^{\circ}$ sebesar $336.583 \mathrm{~N}$.

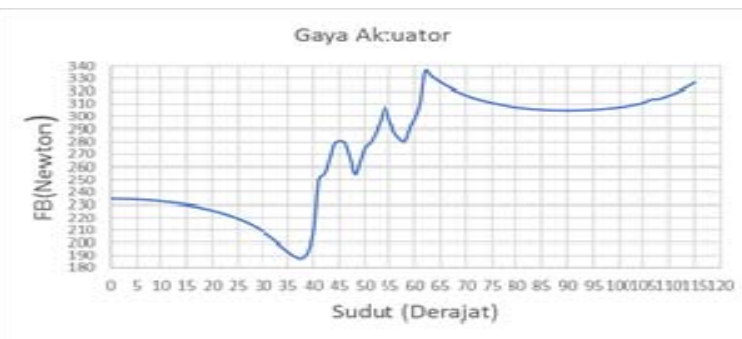

Gbr. 4 Hubungan parameter sudut bukaan bagasi terhadap besaran gaya aktuator yang diperlukan 
Besarnya Torsi selanjutnya dapat ditentukan menggunakan persamaan (8) dan (9),

Dari tabel II, pitch $=6 \mathrm{~mm}=$ Lead L (single start thread),

Pitch diameter $\mathrm{d}=\mathrm{D}-0.5 \mathrm{p}$

$$
\begin{aligned}
& =25-0.5(6) \\
, & =22 \mathrm{~mm}
\end{aligned}
$$

Dari persamaan (10), besarnya sudut helix dapat ditentukan

$$
\begin{aligned}
\tan \theta & =\mathrm{L} /(\Pi \mathrm{d}) \\
& =6 /(\Pi \times 22) \\
& =6 / 69.08=0.086 \\
\theta & =4.92^{\circ}
\end{aligned}
$$

Besarnya sudut $\varphi$ ', dapat dihitung dengan menggunakan persamaan (11), sebagai berikut:

$$
\begin{aligned}
\tan \varphi^{\prime} & =\mu / \cos \alpha \\
& =0,125 / \cos \left(15^{\circ}\right) \\
& =0,1294 \\
\varphi^{\prime} & =7.37^{\circ}
\end{aligned}
$$

Besarnya torsi motor menaikkan bagasi, diperoleh dengan menggunakan persamaan (8).

$$
\begin{aligned}
\mathrm{T} & =\mathrm{F} \mathrm{d} / 2 \tan \left(\varphi^{\prime}+\theta\right) \\
& =336.583 \times(22 / 2) \times \tan (7.37+4.92)^{\circ} \\
& =3702.413 \tan \left(12,29^{\circ}\right) \\
& =806,58 \mathrm{Nmm} \\
& =0,80658 \mathrm{Nm}
\end{aligned}
$$

Besarnya torsi menurunkan bagasi, diperoleh dengan menggunakan persamaan (8).

$$
\begin{aligned}
\mathrm{T} & =\mathrm{F} \mathrm{d} / 2 \tan \left(\varphi^{\prime}-\theta\right) \\
& =336.583 \times(22 / 2) \times \tan (7.37-4.92)^{\circ} \\
& =3702.413 \tan \left(2,45^{\circ}\right) \\
& =158,41 \mathrm{Nmm} \\
& =0,1584 \mathrm{Nm}
\end{aligned}
$$

Pemilihan motor selanjutnya pada perencanaan diambil dengan nilai torsi maksimum yaitu sebesar $0,80658 \mathrm{Nm}$ saat aktuator menaikkan bagasi. Selanjutnya spesifikasi teknik diambil motor DC dengan karakteristik sebagai berikut.

TABEL IIIII

SPSEIFIKASI MOTOR DC

\begin{tabular}{|c|c|}
\hline \multicolumn{2}{|c|}{ Parameter } \\
\hline $12 \mathrm{~V}$ & $120 \mathrm{rpm}$ \\
\hline $24 \mathrm{~V}$ & $250 \mathrm{rpm}$ \\
\hline Torsi & $40 \mathrm{~kg} . \mathrm{cm} ; 3,92 \mathrm{Nm}$ \\
\hline Ratio & $1: 30$ \\
\hline \multicolumn{2}{|c|}{ Dimensi } \\
\hline Panjang motor & $7.6 \mathrm{~cm}$ \\
\hline Lebar/diameter body & $3.1 \mathrm{~cm}$ \\
\hline Diameter as & $6 \mathrm{~mm}$ \\
\hline Panjang as & $1.7 \mathrm{~cm}$ \\
\hline
\end{tabular}

Pemilihan aktuator yang digunakan dalam perencanaan, dengan spesifikasi teknik sebagai berikut.
TABEL IVV

SPSEIFIKASI AKTUATOR

\begin{tabular}{|c|c|}
\hline \multicolumn{2}{|c|}{ Parameter } \\
\hline Input & DC 12 V \\
\hline Speed & $1 \mathrm{~cm} / \mathrm{s}$ \\
\hline Material & Metal \\
\hline Tipe & Linear aktuator \\
\hline Stroke length & $11.7 \mathrm{~cm}$ \\
\hline Total length & $44.2 \mathrm{~cm}$ \\
\hline Weight & $1200 \mathrm{gr}$ \\
\hline
\end{tabular}

Peletakan aktuator dalam rancangan ditampilkan dalam gambar 5 .

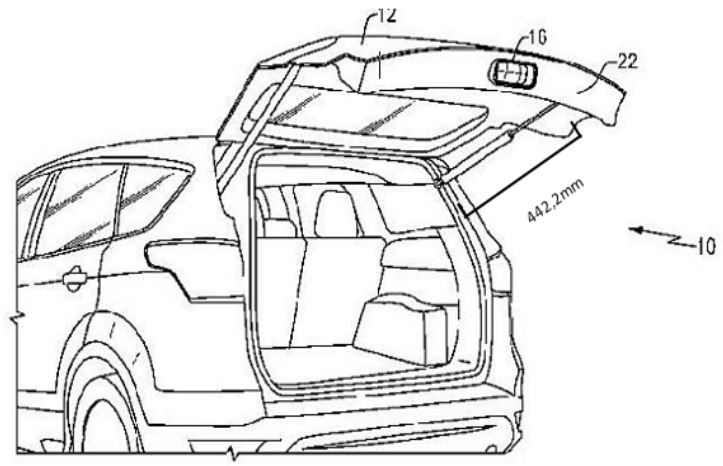

Gbr. 5 Peletakan aktuator di dalam kendaraan

Implementasi sumber energi listrik yang digunakan bersumber dari aki kendaraan tersebut. Untuk memenuhi spesifikasi motor DC yang digunakan menyesuaikan merk dan tipenya aki. Spesifikasi tekniknya aki kendaraan tersebut dengan kapasitas 35 Ah (Ampere hour) dengan tegangan $12 \mathrm{~V}$ [10].

Sakelar untuk pemutus dan penyambung arus dalam sistem jaringan kelistrikannya dan sensor yang menggunakan sakelar toggle switch 3-Pin KCD1-105 Rocker Switch With 12V LED - Hole $20 \mathrm{~mm}$ (Red). Dalam hal ini, ketika pada posisi off sensor tidak mendeteksi gerakan begitu juga sebaliknya jika posisi on maka sensor bisa mendeteksi gerakan. Selain itu untuk mengantispasi terjadi arus yang berlebihan pada sistem ini dipasang fuse dengan blade 10A yang di implementasikan pada jalur arus dari aki ke semua rangkaian seperti regulator, aktuator, door lock, dan mesin.

Relay pada rangkaian ini berfungsi seperti pelatuk untuk menggerakan aktuator ketika sensor mendeteksi Gerakan. Maka aktuator akan bergerak membuka pintu bagasi ketika keadaan tertutup dan menutup ketika pada kondisi terbuka

Regulator pada rangkaian ini berfungsi untuk memasok arus pada arduino sesuai kebutuhan yang diperlukan yaitu $5 \mathrm{~V}$ dari arus yang sebelumnya diterima sebesar $12 \mathrm{~V}$ dari aki. Selain itu regulator juga memasok arus untuk LCD. Regulator yang digunakan Regulator DC To DC $12 \mathrm{~V}$ To $5 \mathrm{~V}$ 3A Power Converter Step-Down Buck Module Jielaite. 
Regulator dalam hal ini berperan untuk menurunkan dan mempertahankan tegangan pada level tertentu secara otomatis.

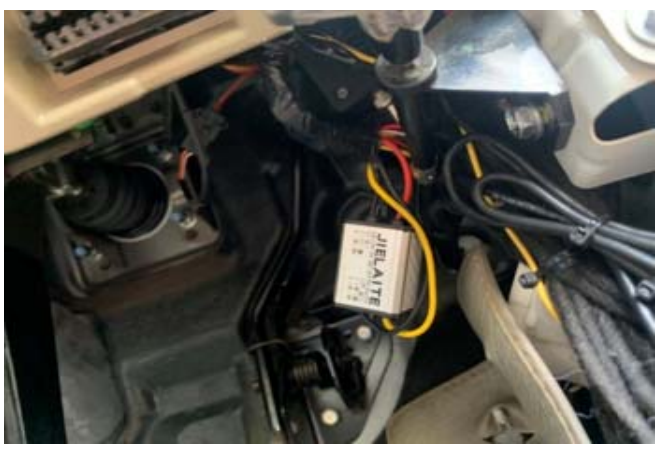

Gbr. 6 Regulator yang dipergunakan

Arduino UNO sebagai pemproses dari input dalam hal ini adalah sensor motion detector yang kemudian diolah dengan beberapa input yang lain antara lain kondisi door lock dan engine sebagaimana gambar 7. Kemudain mengeluarkan reaksi terhadap beberapa inputan di atas untuk menggerakan aktuator melalui relay [11].

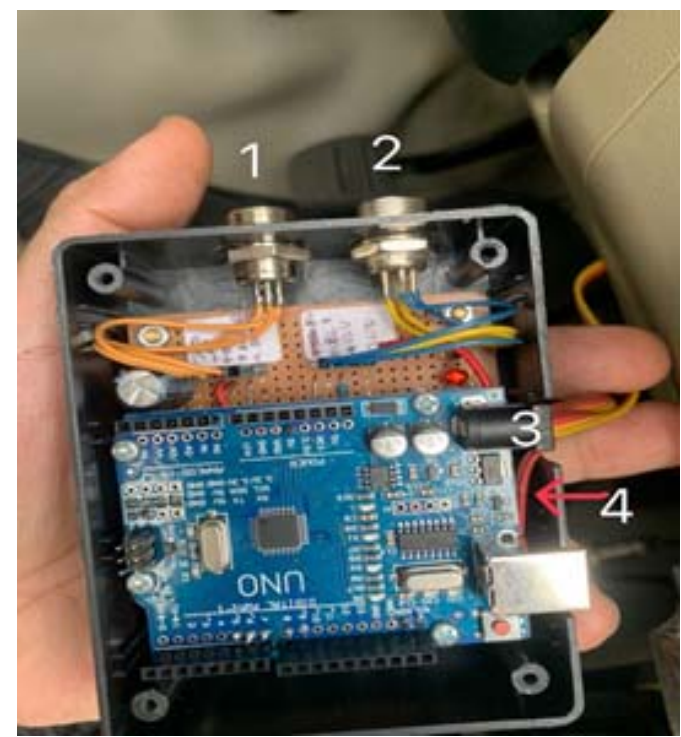

\section{Input 5V 2. Input 5V 3. Output LCD 4. Output aktuator}

Gbr. 7 Arduino UNO pemrosesan input data

Pada perancangan dan pembuatan mekanisme sistem pembukaan bagasi dengan bantuan kick foot sensor yaitu, menggunakan motion sensor passive infrared. Passive infrared receiver merupakan sebuah sensor berbasis infrared. Akan tetapi, tidak seperti sensor infrared kebanyakan yang terdiri dari IR LED dan fototransistor. PIR tidak memancarkan apapun seperti IR LED. Sesuai dengan namanya "Passivee, sensor ini hanya merespon energi dari pancaran sinar inframerah pasif yang dimiliki oleh setiap objek bergerak yang terdeteksi olehnya [12].
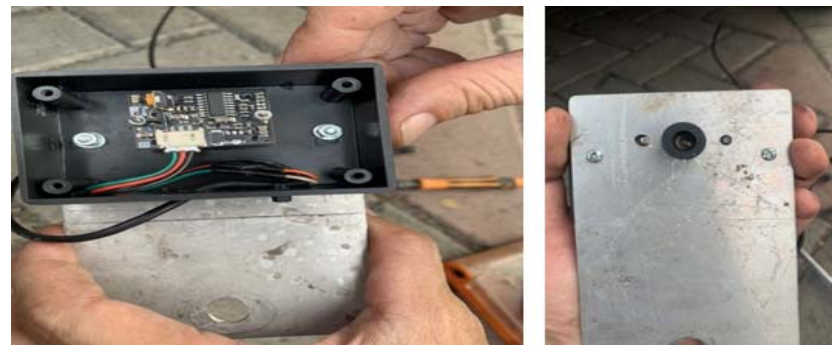

Gbr. 8 Motion sensor tampak atas dan bawah

Tahapan kedua, adalah melakukan pengujian pada saat membuka dan menutupnya berdasarkan durasi waktunya. Kemudian dilanjutkan dengan menguji sensitivitas sensor.

Implementasi wiring diagram rangkaian kelistrikan dan komponen pendukung sebagai sebuah mekanisme kerja lengkapnya sebagai fitur membuka dan menutup pada sistem bagasi otomatis ditunjukkan dalam skema seperti gambar 9 .

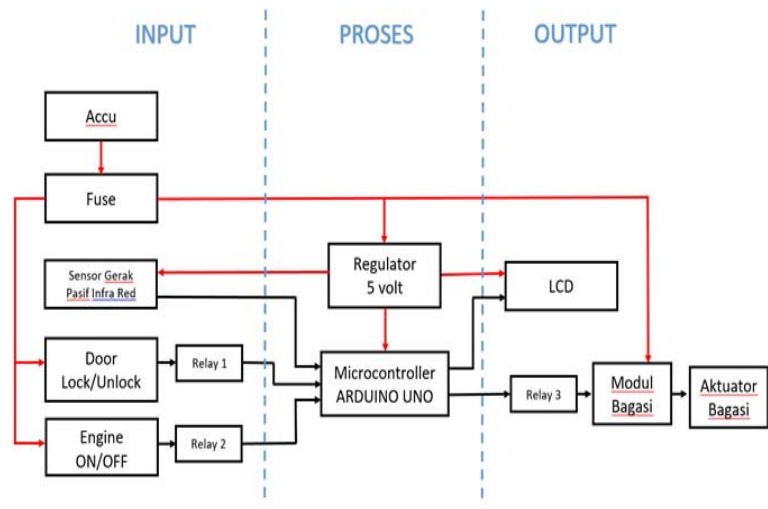

Gbr. 9 Skema wiring diagram

\section{HASIL DAN DISKUSI}

Setelah semua komponen sudah terpasang dan tidak menggangu estetika kendaraan dan fungsi utama dari bagasi, dilanjutkan eksperimen. Eksperimen uji coba pada power tailgate dan kick foot sensor memperhatikan pedoman untuk mendapatkan hasil yang baik. Pedoman yang digunakan untuk mengetahui baik tidaknya kinerja mekanisme bagasi otomatis dengan foot sensor ini adalah dengan membuka pintu bagasi menggunakan satu ayunan kaki pada bagian bawah sensor. Pada pegujian awal, gerakan yang terlalu cepat membuat sensor tidak membaca gerakan karena itu ditambahkan selang karet pada bagian pembaca sensor. Supaya sensor membaca fokus pada titik di bawah bagasi tidak menyebar. Setelah percobaan berikutnya diulang lagi apakah motion sensor sudah membaca dengan lebih fokus dengan bantuan selang karet yang diberikan. Akhirnya, karet pelindung diimplementasikan pada kendaraan yang sekaligus pelindung. Setelah menggunakan metode ini ditemukan bahwa media 
pembaca sensor sudah lebih fokus dengan jangkauan yang tidak terlalu melebar dan sensor dapat membaca dengan baik pada saat kaki tepat berada di bawah sensor. Berikut ini hasil pengujian untuk membuka dan menutup bagasi kendaraan tersebut.

TABEL V

PENGUJIAN DAN MEMBUKA PINTU BAGASI

\begin{tabular}{|c|c|}
\hline \multicolumn{2}{|c|}{ Proses Pembukaan (detik) } \\
\hline 1 & 11.78 \\
\hline 2 & 11.84 \\
\hline 3 & 11.75 \\
\hline Rerata & $\mathbf{1 1 , 7 9}$ \\
\hline 12 & 11.56 \\
\hline 2 & 11.52 \\
\hline 3 & 11.60 \\
\hline Rerata & $\mathbf{1 1 . 5 6}$ \\
\hline
\end{tabular}

Dari hasil pengujian tersebut terlihat bahwa dari percobaan 1-3 menunjukkan memang tidak terlihat perbedaan yang signifikant dari masing masing data hasil percobaan pada saat proses pembukaan bagasi, karena pada tingkat kepercayaan 95\% data masih berada pada range valid yaitu berada pada kisaran $(11,6762 ; 11,9038)$. Demikian halnya juga pada proses menutup pintu bagasi dengan tingkat kepercayaan 95\% data hasil percobaan masih berada pada range valid $(11,4606$; 11,6594).

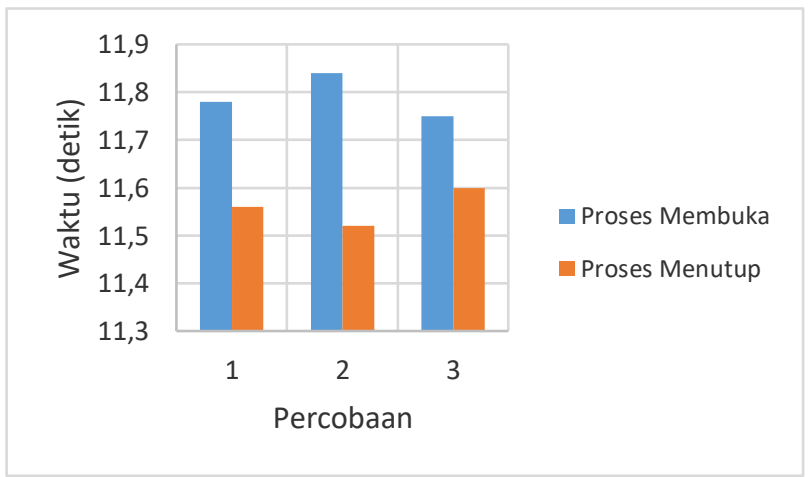

Gbr. 10 Durasi proses membuka dan menutup bagasi terlihat tidak identik

Jika dilakukan uji paired test artinya proses membuka dan menutup tidak identik secara significant hal ini disebabkan besarnya torsi saat membuka dan menutup memang tidak sama besar karena menggunakan sistem ulir. Pernyataan tersebut juga dikuatkan berdasarkan hasil percobaan proses membuka dan menutup pintu bagasi tersebut terhadap durasinya dalam detik, sebagaimana ditunjukkan dalam gambar 10 .
Selanjutnya, pada pengujian sensitivitas motion sensor sebagaimana ditunjukkan dalam gambar 11, diperoleh sebagai berikut.

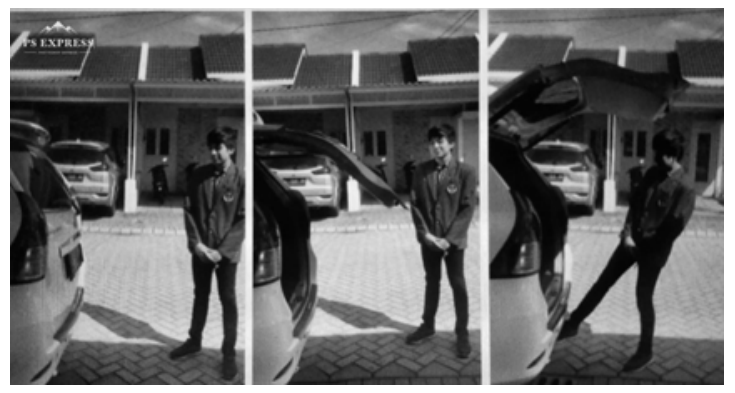

Gbr. 11 Pengujian kemampuan sensitivitas kick foot sensor

TABEL VV

UJI SENSITIVITAS SENSOR TERHADAP JARAK

\begin{tabular}{|c|c|c|}
\hline Percobaan & Jarak (cm) & Sensor mendeteksi \\
\hline 1 & 2 & ya \\
\hline 2 & 20 & ya \\
\hline 3 & 40 & ya \\
\hline
\end{tabular}

Dari hasil pengujian kemampuan motion sensor membaca gerakan kaki pada range 2 hingga $40 \mathrm{~cm}$, lebih dari tersebut tetap terdeteksi namun tidak dengan satu kali ayunan kaki tapi bisa lebih dari satu ayunan kaki untuk proses membuka dan menutup pintu bagasi tersebut. Tidak ada pengaruh sensitivitas jarak yang diberikan saat mengayunkan kaki dengan lama waktu dalam membuka dan menutup pintu bagasi, hal ini karena sensor hanya berfungsi untuk melakukan koneksi saja sehingga proses dapat berlangsung dengan baik atau tidak menangkap sinyal gerakan kaki tersebut.

\section{KESIMPULAN}

Hasil penelitian ini tentang pemanfaatan kick foot sensor untuk mekanisme buka tutup bagasi kendaraan dapat disimpulkan sebagai berikut ini:

- Kick foot sensor dapat bekerja dengan baik menghubungkan komponen komponen seperti aki, fuse, sakelar, motion sensor, Arduino, relay, dan aktuator dengan menggunakan mekanisme ulir.

- Dari hasil pengujian diperoleh waktu untuk membuka bagasi rata-rata sebesar 11,79 detik, sedangkan waktu untuk menutupnya rata rata sebesar 11,56 detik. Waktu yang diperoleh ini lebih cepat dibanding target awal perancangan yang ditetapkan 15 detik baik saat membuka maupun menutup bagasi. Proses membuka dan menutup tidak identik secara significant hal ini disebabkan besar torsi saat membuka dan menutup memang tidak sama karena menggunakan sistem ulir. 
- Pada pegujian awal, gerakan yang terlalu cepat membuat sensor tidak membaca gerakan karena itu ditambahkan selang karet pada bagian pembaca sensor supaya terarah. Dalam hal ini, sensor berhasil membaca fokus pada titik di bawah bagasi atau bumper dan tidak menyebar. Setelah menggunakan metode ini ditemukan bahwa media pembaca sensor sudah lebih fokus dengan jangkauan yang tidak terlalu melebar dan sensor dapat membaca dengan baik pada saat kaki tepat berada di bawah sensor. Kemampuan motion sensor membaca gerakan kaki pada range ideal 2 hingga $40 \mathrm{~cm}$, lebih dari tersebut tetap terdeteksi namun tidak dengan satu kali ayunan kaki tapi bisa lebih dari satu ayunan kaki untuk proses membuka dan menutup pintu bagasi tersebut.

\section{UCAPAN TERIMA KASIH}

Terimakasih kepada rekan rekan staf pengajar otomotif di Prodi Teknik Mesin, Universitas Kristen Petra yang telah memberikan masukan dan penyempurnaan melalui diskusi dan tanya jawab selama periode pengujian alat ini berlangsung.

\section{REFERENSI}

[1] Abhijeet S. Salunkhe, Kashinath H. Munde, Ashish R. Pawar," Optimization of Power Lif Gate Spindle \& Socket Assembly," Journal of Analysis and Computation (JAC), Volume - XIV, Issue VII, JULY 2020.

[2] Rubi, Chhavi Rana," A Review: Speech Recognition with Deep Learning Methods," International Journal of Computer Science and Mobile Computing, Vol.4 Issue.5, hal 1017-1024, May- 2015.

[3] Ashok Kumar, Vikas Mittal," Speech Recognition: A Complete Perspective," International Journal of Recent Technology and Engineering (IJRTE) ISSN: 2277-3878, Volume-7 Issue-6C, April 2019

[4] Richard P. Lippmann," Speech recognition by machines and humans," Elsevier, Speech Communication 22, hal 1-15, 1997.

[5] Munshi Yadav, M. Afshar Alam," Speech Recognition: A Review," IJRECE, vol. 6, hal 481-489, Mar. 2018.

[6] Varsha Hotur, Usha N S," Speech Recognition Interactive System for Vehicles." International Journal of Current Engineering and Scientific Research (IJCESR), volume-5, Issue-5, hal 31-35, 2018.

[7] Jinapriya, S,"AI and Human Interaction," International Journal of Current Research Vol. 12, Issue, 01, pp.9185-9187, January, 2020

[8] New South Wales. Technical and Further Education Commission. Manufacturing and Engineering Educational Services.”Mechanical Design Data Manual.” Bankstown, N.S.W. : Manufacturing and Engineering Educational Services, N.S.W. TAFE Commission, hal..323-337, 2000.

[9] Richard G. Budynas and J.Keith Nisbett, Shigley's Mechanical Engineering Design, 9 th ed, McGraw-Hill Companies, 2012.

[10] (2014) Astra Otoparts website. [online], https://aki.gsastra.com/tentang-astra-otoparts, tanggal akses: 25 Agustus 2021

[11] Alan G Smith, Introduction to Arduino, hal 1-172, September 2011

[12] Rozali Toyib, Iwan Bustami, Dedy Abdullah, Onsardi," Penggunaan Sensor Passive Infrared Receiver (PIR) untuk mendeteksi Gerak Berbasis Short Message Servis Gateway," Jurnal Pseudocode, Volume VI Nomor 2, hal 114-124, September 2019. 